\title{
Effect of Different Preservative Solutions on Post-Harvest Life of Cut Rose (Rosa hybrida L.) cv. "Blush"
}

\author{
Aqiba Qureshi $^{1 *}$, Youdh Chand Gupta ${ }^{2}$, Sita Ram Dhiman ${ }^{1}$, Bharati Kashyap ${ }^{1}$, \\ Rakesh Kumar Gupta ${ }^{3}$ and Manisha Kaushal ${ }^{4}$
}
${ }^{1}$ Department of Floriculture and Landscape Architecture, ${ }^{2}$ College of Horticulture \& CEHRE, ${ }^{3}$ Department of Basic Sciences, ${ }^{4}$ Department of Food science and Technology Dr Yashwant Singh Parmar University of Horticulture and Forestry, Nauni, Solan, HP-173230, India

*Corresponding author

\section{A B S T R A C T}

\section{Keywords}

Bud- opening, 8- HQC, Index, Rosa hybrida L., Sucrose,

Vase Life

Article Info

Accepted:

04 October 2019

Available Online:

10 November 2019
In the present study, the effect of preservative solutions on bud opening and vase life of rose cv. "Blush" was observed for three flowering seasons viz., MarchApril, June- July, and September- October in the year 2018- 19. The cut rose stems (before unfurling of petals) were treated with solutions viz., $\mathrm{T}_{1}$ : Control (Distilled Water), $\mathrm{T}_{2}$ : Sucrose $(1.5 \%)+8$-HQC $(50 \mathrm{ppm}), \mathrm{T}_{3}$ : Sucrose $(1.5 \%)+8-$ HQC (100 ppm), $\mathrm{T}_{4}:$ Sucrose (3\%) + 8-HQC (50 ppm) and $\mathrm{T}_{5}:$ Sucrose $(3 \%)+8-$ HQC (100 ppm) under completely randomized design (factorial) with five replications. The results showed considerable significant variation in post- harvest parameters of cut rose cultivar "Blush" in response to the treatment with preservative solutions containing sucrose as an exogenous source of carbohydrates and 8- HQC as a germicide. It was observed that the treatment of cut roses with solution comprising of Sucrose $(3 \%)+8$-HQC $(100 \mathrm{ppm})$ resulted in best treatment for bud opening index $(1.50,1.32 \& 1.25)$,volume of solution consumed $(29.07,36.60 \& 24.40 \mathrm{ml})$, volume of distilled water consumed $(45.67,52.26 \&$ $59.20 \mathrm{ml}$ ), days taken for bud opening (3.60,5.20 \& 6.80 days), and vase life $(10.00,13.80 \& 13.13$ days) in all the three seasons, respectively.

\section{Introduction}

Rose (Rosa hybrida L.) belongs to the family Rosaceae under which comes more than 150 species and 1400 cultivars (Synge, 1971; Elgimabi, 2011). Rose ranks first among the cut flowers both in the Indian domestic as well as international markets. Cut roses are symbol 
of love, adoration, beauty and innocence. Due to the great diversity, slow opening of flowers and excellent keeping quality, roses are popular cut flowers that have been grown commercially in protected structures to meet the quality standards in the market. Rose is regarded as the queen of flowers, but the vase life of cut roses is usually short (Gerailoo and Ghasemnezhad, 2011). Rose has been recognized for their high economic values as they provide raw material for agro-based industry viz. cosmetic, perfumery, and has important role in medicine and nutrition (Butt, 2003). With market globalization quality management of cut roses is a necessity, and vase life is an essential attribute of quality of any cut flower.

Prior to harvest, flowers are supplied continuously with carbohydrates, produced by photosynthesis that occurs in the green leaves of the plant, which enables it to transform itself from a bud to bloom. The phase of flower development encompasses one of the most active growth periods in all of plant development. Flower development and opening are critical to provide attractive blooms. The vase life and quality of many flowers, particularly those cut as spikes or tight buds is a function of continued and adequate development and opening of young buds (Evans and Reid, 1986).

Commercially roses are harvested at bud stage as buds have a longer vase life, are less sensitive to ethylene, easy to handle during storage and transport and are less prone to disease and pest attacks.

Rose buds are expected to open fully before senescing, but the amount of carbohydrates present in the flower bud at harvesting is not sufficient to support respiration, maintenance and osmoregulation during vase life, thus there must be import of carbohydrates into the bud, which is considered to be a sink
(Marissen and Brijn, 1995). A lack of carbohydrates can cause the bud of a cut rose flower not to open (van Doorn et al., 1996). Flower bud opening can be sustained by the simple preservative solutions indicating that the primary components of the bud are present from very early in development and that a sugar supply is all that is required to drive floral development (Reid, 2005). Sugar can be used to compensate for lack of carbohydrate solution (Ichimura and Hiraya, 1999), but sucrose alone has not been usually used because sugar treatment without germicides promotes bacterial proliferation, leading to shortening of the vase life.

Thus the objective of present study was to determine the effect preservative solution consisting of different concentrations of sucrose and 8- hydro- quinoline citrate (8HQC) on postharvest life of cut rose cv. "Blush".

\section{Materials and Methods}

The experiment was carried out at the Hi-tech farm of the Department of Floriculture and Landscape Architecture of Dr. Yashwant Singh Parmar University of Horticulture and Forestry, Nauni, Solan (HP) during the three seasons of the year 2017-2018.

The cut flower stems of uniform length, harvested before the unfurling of petals, were put in the test tubes filled with bud- opening solutions viz., $\mathrm{T}_{1}$ : Control (Distilled Water), $\mathrm{T}_{2}$ : Sucrose $(1.5 \%)+8$-HQC (50 ppm), $\mathrm{T}_{3}$ : Sucrose $(1.5 \%)+8$-HQC (100 ppm), $\mathrm{T}_{4}$ : Sucrose $(3 \%)+8$-HQC (50 ppm) and $\mathrm{T}_{5}$ : Sucrose $(3 \%)+8$-HQC (100 ppm) under completely randomized design with five replications. After treating the flowers with bud- opening solution, the cut stems were placed in test tubes containing distilled water to determine the vase life and other parameters. 
The following data were recorded: Bud opening index, Volume of solution consumed (ml), Volume of distilled water consumed (ml), Days to flower bud opening (days) and Vsase life (days).

\section{Statistical Analysis}

The data collected were analysed using MSExcel and OPSTAT (Sheoran et al., 1998). The mean values of data were subjected to analysis of variance as described by Panse and Sukhatme (2000) for using Completely Randomized Design (Factorial CRD).

\section{Results and Discussion}

\section{Bud Opening Index}

A significant difference in bud opening index was observed among the treatments for all three seasons (viz., March- April, June- July and September- October). The maximum opening index score (1.50, 1.32 and 1.25) was recorded in cut stems treated with T5 (3\% Sucrose $+100 \mathrm{ppm} \mathrm{8-HQC)}$ for the three seasons, respectively. However, minimum score was observed in the season March- April was recorded with T1 (Distilled water)\& T2 (1.5\% Sucrose +50 ppm 8-HQC) as 1.22 and in the seasons June- July and SeptemberOctober with $\mathrm{T} 2$ as 1.15 and 1.10, respectively. Development of flower bud requires carbohydrate and sucrose otherwise could not open naturally (Pun and Ichimura, 2003) as it provides an essential substrate for respiration, structural material and carbon skeletons for bud opening (Mayak et al., 1973). Sarkka (2005) suggested that carbohydrates are necessary for turgor pressure maintenance and relevant energy sources facilitating flower opening. However, the reduction in the uptake of carbohydrates from the preservative solutions that contained sucrose, affecting the flower bud opening, maybe due to the blockage of xylem.

\section{Volume of solution consumed (ml)}

Recorded data determines that the maximum solution uptake $(29.07,36.60$ and $24.40 \mathrm{ml}$ ) was recorded in rose cut stems treated with T5 and minimum solution (16.73, 28.20 and $12.07 \mathrm{ml}$ ) was consumed by the cut stems placed in distilled water for all the three seasons (Table 1, 2 and 3). Cut flowers get necessary food from sucrose and the germicidal action from 8 HQC, which prevents vascular blockage and that may be responsible for the maximum solution uptake. Nowak and Rudnicki (1990) also reported that8-HQC improved flower longevity by decreasing microbial growth in vascular bundles and increased tendency of cut flowers to absorb more solution. These results are following the finding of Marousky (1969), who reported that vascular blockage was avoided by inclusion of 8-HQC and hence cut flower absorbed maximum amount of solution.

\section{Volume of distilled water consumed (ml)}

In all the three seasons, a higher volume of distilled water (45.67, 52.26 and $59.20 \mathrm{ml}$ )was consumed by $\mathrm{T} 5$ as compared to the $\mathrm{T} 1$ (29.33, 32.73 and $36.67 \mathrm{ml})$. An important factor contributing to low vase life is the vascular blockage caused by microorganisms clustering at the bottom of the cut stem (Van Doorn et al., 1990). The present findings are in conformity that the use of preservative solutions containing germicides like 8-HQC ensure avoiding vascular blockages caused by microorganisms, increasing the water uptake and the vase life. 
Table.1 Effect of preservative solutions on the flower bud opening index, volume of solution consumed, volume of distilled water consumed, days to flower bud opening and vase life of rose (Rosa hybrida L.) cv. "Blush" during March- April(2018- 19)

\begin{tabular}{|l|c|c|c|c|c|c|c|}
\hline \multicolumn{1}{|c|}{ Treatment } & T1 & T2 & T3 & T4 & T5 & Mean & $\begin{array}{c}\text { C. D. } \\
(\mathbf{0 . 0 5})\end{array}$ \\
\hline Flower bud opening Index & 1.22 & 1.22 & 1.24 & 1.38 & 1.50 & 1.31 & 0.03 \\
\hline $\begin{array}{l}\text { Volume of solution consumed } \\
\text { (ml) }\end{array}$ & 16.73 & 20.40 & 23.87 & 23.80 & $\mathbf{2 9 . 0 7}$ & 22.77 & 2.38 \\
\hline $\begin{array}{l}\text { Volume of distilled water } \\
\text { consumed(ml) }\end{array}$ & 29.33 & 37.47 & 39.73 & 37.27 & $\mathbf{4 5 . 6 7}$ & 37.89 & 3.91 \\
\hline $\begin{array}{l}\text { Days to flower bud opening } \\
\text { (days) }\end{array}$ & 5.80 & 4.93 & 4.07 & 4.73 & $\mathbf{3 . 6 0}$ & 4.63 & 0.44 \\
\hline Vase life (days) & 6.26 & 7.00 & 7.40 & 9.60 & $\mathbf{1 0 . 0 0}$ & 8.05 & 0.81 \\
\hline
\end{tabular}

Table.2 Effect of preservative solutions on the flower bud opening index, volume of solution consumed, volume of distilled water consumed, days to flower bud opening and vase life of rose (Rosa hybrida L.) cv. "Blush" during June- July (2018-19)

\begin{tabular}{|l|c|c|c|c|c|c|c|}
\hline \multicolumn{1}{|c|}{ Treatment } & T1 & T2 & T3 & T4 & T5 & Mean & $\begin{array}{c}\text { C. D. } \\
(\mathbf{0 . 0 5})\end{array}$ \\
\hline Flower bud opening index & 1.17 & 1.15 & 1.18 & 1.21 & 1.32 & 1.20 & 0.08 \\
\hline $\begin{array}{l}\text { Volume of solution } \\
\text { consumed (ml) }\end{array}$ & 28.20 & 31.67 & 33.33 & 34.14 & 36.60 & 32.79 & 3.65 \\
\hline $\begin{array}{l}\text { Volume of distilled water } \\
\text { consumed(ml) }\end{array}$ & 32.73 & 42.27 & 42.27 & 42.93 & 52.26 & 42.49 & 3.73 \\
\hline $\begin{array}{l}\text { Days to flower bud } \\
\text { opening (days) }\end{array}$ & 7.27 & 6.47 & 5.93 & 6.27 & 5.20 & 6.23 & 0.55 \\
\hline Vase life (days) & 7.93 & 10.27 & 10.40 & 12.33 & 13.80 & 10.95 & 0.82 \\
\hline
\end{tabular}

Table.3 Effect of preservative solutions on the flower bud opening index, volume of solution consumed, volume of distilled water consumed, days to flower bud opening and vase life of rose (Rosa hybrida L.) cv. "Blush" during September-October (2018-19)

\begin{tabular}{|l|c|c|c|c|c|c|c|}
\hline \multicolumn{1}{|c|}{ Treatment } & T1 & T2 & T3 & T4 & T5 & Mean & $\begin{array}{c}\text { C. D. } \\
(\mathbf{0 . 0 5})\end{array}$ \\
\hline Flower bud opening index & 1.14 & 1.10 & 1.14 & 1.19 & 1.25 & 1.16 & 0.07 \\
\hline $\begin{array}{l}\text { Volume of solution } \\
\text { consumed (ml) }\end{array}$ & 12.07 & 15.20 & 16.13 & 17.40 & 24.40 & 17.04 & 1.82 \\
\hline $\begin{array}{l}\text { Volume of distilled water } \\
\text { consumed(ml) }\end{array}$ & 36.67 & 47.53 & 45.33 & 49.27 & 59.20 & 47.60 & 4.93 \\
\hline $\begin{array}{l}\text { Days to flower bud opening } \\
\text { (days) }\end{array}$ & 8.53 & 7.67 & 7.33 & 7.20 & 6.80 & 7.51 & 0.80 \\
\hline Vase life (days) & 7.00 & 8.47 & 9.07 & 11.33 & 13.13 & 9.80 & 0.96 \\
\hline
\end{tabular}




\section{Days taken for flower bud opening (days)}

Days taken for flower bud opening varied significantly among the treatments for all three seasons, as shown in Tables 1, 2 and 3 . However, maximum days for bud opening were taken by $\mathrm{T} 1$ (5.80, 7.27 and 8.53 days) while the minimum was recorded with $\mathrm{T} 5$ (3.60, 5.20 and 6.80 days) in the three seasons, respectively. Flower opening is dependent on carbohydrate levels in the petal (Van Doorn et al., 1991), and petal growth is associated with flower bud opening, which results from cell expansion, and this requires the influx of water and carbohydrates into petal cell (Evan and Reid, 1988). The sugars and biocide solutions are useful for opening bud cut flowers like gladiolus, carnation, chrysanthemum and freesia (Bhattacharjee, 1999).

\section{Vase life (days)}

The preservative solutions used for bud opening had a significant effect on the vase life of cut rose buds in all three seasons. The use of distilled water caused the shortest vase life (6.26, 7.93 and 7.00 days). However, maximum duration of vase life was recorded with cut stems treated with T5 (10.00, 13.80 and 13.13 days) in March- April, June- July and September- October, respectively. The concentration of soluble carbohydrates is a factor that controls the vase life of cut roses because the carbon source of cut flowers is limited (Halevy and Mayak, 1979). Sucrose can act as a source of nutrition for tissues approaching carbohydrate starvation, flower opening and subsequent water relations; thus, Kuiper et al., (1995) suggested that sucrose can supply increases the longevity of many cut flowers. The present findings got support from the studies of Nagarajuna et al., (2002); Nijasure et al., (2004) in gladiolus; Shafiqa and Barket (2015) in iris and Prakash (2017) in china aster.
Based on the data recorded, it can be concluded that the solution containing $1.5 \%$ Sucrose +50 ppm 8-HQC had a significant effect on the rose cultivar 'Blush' recording maximum bud opening index, the volume of solution and distilled water consumed. Minimum days were taken for flower bud opening and longer duration of vase life was observed in cut rose stems treated with $1.5 \%$ Sucrose + 50 ppm 8-HQC.

\section{Acknowledgment}

The experimental costs were supported by the Department of Floriculture and Landscape Architecture, Dr. Yashwant Singh Parmar University of Horticulture and Forestry, Nauni, Solan, HP-173230, India.

\section{Author's contributions}

The experiment was conducted to fulfill a part of the Ph.D. thesis of Aqiba Qureshi advised by Dr Youdh Chand Gupta. Dr Sita Ram Dhiman, Dr Bharati Kashyap, Dr Rakesh Kumar Gupta and Dr Manisha Kaushal are the committee members of the advisory of the Ph. $\mathrm{D}$ research who have helped in designing the research programme, data analysis and laboratory work.

\section{References}

Bhattacharjee, S.K. 1999. Postharvest management of cut flowers, cut foliages and post production management of potted plants. Journal of Ornamental Horticulture, 2: 32-39.

Butt, S.J. 2003. A review on prolonging the vase life of roses. Pakistan Rose Annual, Published by Pakistan National Rose Society, pp. 49-53.

Elgimabi, M.E.N.E. 2011. Vase life extension of Rose cut flowers (Rosa hybrida) as influenced by silver nitrate and sucrose pulsing. American Journal of 
Agricultural and Biological Sciences 6(1): 128-133.

Evans, R. Y. and Reid, M. S. 1988. Changes in carbohydrates and osmotic potential during rhythmic expansion of rose petals. Journal of the American Society for Horticultural Science 113: 884888.

Gerailoo, S. and Ghasemnezhad, M. 2011. Effect of salicylic acid on antioxidant enzyme activity and petal senescence in 'Yellow Island' cut rose flowers. Journal of Fruit and Ornamental Plant Research 19, 183-193.

Halevy, A. H. and Mayak, S. 1979. Senescence and postharvest physiology of cut flowers, part 1.Horticultural Reviews 1: 204- 236.

Ichimura, K. and Hiraya, T. 1999. Effect of silver thiosulfate complex (STS) in combination with sucrose on the vase life of cut sweet pea flowers. Journal of the Japanese Society for Horticultural Sciences 68: 23- 27.

Kuiper, D., Ribots, V., Van Reen, H. S. and Marissenn, N. 1995. The effect of sucrose on the flower bud opening of "Madelon" cut roses. Scientia Horticulturae 60: 325-336

Marissen, N. and La Brijn, L. 1995. Sourcesink relations in cut roses during vase life. In VI International Symposium on Postharvest Physiology of Ornamental Plants 405: 81- 88

Mayak, S.,Bravdo, B.,Guilli, A. and Halvey, A. H. 1973. Improvement of opening of cut galadioli flower by pretreatment with high sucrose concentrations. Scientia Horticulturae 1: 357-365

Marousky, F. G. 1969.Vascular blockage, water absorption, stomatal opening and respiration of cut "Better Times" roses treated with 8-hydroxyquinoline citrate and sucrose. Journal of the American Society for Horticultural Science 94: 223-226.
Reid, M. S. 2005. Flower Development: From Bud to Bloom. Proc. VIIIth IS Postharvest Phys. Ornamentals Eds. N. Marissen et al., Acta Horticulture 669

Nagarjuna, H. T., Narayanagowda J. V. and Nagaraja, G. S. 2002. Effect of pulsing with sucrose on vase life of tuberose cv. "Double". Crop Research23:349353

Nijasure, S. N., Ranpise S. A. and Gondhali, B. V. 2004. Postharvest life of gladiolus cv. "American Beauty" as influenced by floral preservatives. Journal of Ornamental Horticulture 7: 381-385 (2004)

Nowak, J. and Rudnicki, R. M. 1990. Postharvest handling and storage of cut flowers, florist green and potted plants. Timber Press, INC. Portland, Oregon. $210 p$

Panse, V.G. and Sukhatme, P.V. 2000. Statistical Methods for Agricultural Workers, Indian Council of Agricultural Research, New Delhi. 695 p.

Prakash, C. 2017. Studies on Postharvest Handling of China Aster (Callistephus chinensis (L.) Nees.) cv. "Kamini". MSc Thesis. Department of Floriculture and Landscape Architecture, Dr YS Parmar University of Horticulture and Forestry, Solan. $55 \mathrm{p}$

Pun, U. K. andIchimura, K. 2003.Role of sugars in senescence and biosynthesis of ethylene in cut flowers. Japan Agricultural Research Quarterly 4: 219-224

Sarkka, L. 2005. Yield, quality and vase life of cut roses in year- round greenhouse production. Academic Dissertation, University of Helsinki, Finland. 64pp

Shafiqa, M. and Barket. A.2015. Influence of pulsing treatment on post-harvest longevity of spikes of Dutch Iris (Irishol landica). Journal of 
Functional and Environmental Botany 5:47-52

Sheoran, O. P, Tonk, D. S., Kaushik, L. S., Hasija, R. C. and Pannu, R. S. 1998. Statistical Software Package for Agricultural Research Workers. Recent Advances in information theory, Statistics and Computer Applications by D.S. Hooda \& R.C. Hasija Department of Mathematics Statistics, CCS HAU, Hisar., Pp. 139-143.

Synge, P. M. 1971. The dictionary of rose in color. 1st Edn., Madison Square Press, New York, ISBN-10: 0448025043, $191 p$.

Van Doorn, W. G. and Vojinovic, A. 1996.
Petal abscission in rose flowers: Effects of water potential, light intensity and light quality. Annals of Botany 78: 619- 623 (1996).

Van Doorn, W. G., De Witte, Y. and Perik, R. R. J. 1990. Effect of antimicrobial compounds on the number of bacteria in stems of cut rose flowers. Journal of Applied Bacteriology 68: 117-122 (1990).

Van Doorn, W. G., Zagory D., Witle Y de and Harkema, H. 1991. Effects of vase water bacteria on the senescence of cut carnation flowers. Postharvest Biology and Technology 1: 161-168.

\section{How to cite this article:}

Aqiba Qureshi, Youdh Chand Gupta, Sita Ram Dhiman, Bharati Kashyap, Rakesh Kumar Gupta and Manisha Kaushal. 2019. Effect of Different Preservative Solutions on Post-Harvest Life of Cut Rose (Rosa hybrida L.) cv. "Blush". Int.J.Curr.Microbiol.App.Sci. 8(11): 98-104. doi: https://doi.org/10.20546/ijcmas.2019.811.012 